\title{
New Features and Trends of Higher Education during the Epidemic Period
}

\author{
Bin Yan $^{1}$ Joseph Eleojo Victor ${ }^{12^{*}}$ Oguche Innocent Amodu ${ }^{3}$ \\ 1. School of Civil Engineering, Central South University, Changsha, Hunan, 410075, China \\ 2. Department of Civil Engineering, Faculty of Engineering, Ahmadu Bello University Zaria, Kaduna State, 800242 , \\ Nigeria \\ 3. Department of Civil Engineering, Faculty of Engineering, University of Abuja, Abuja, 900105, Nigeria
}

\begin{tabular}{|c|c|}
\hline ARTICLE INFO & ABSTRACT \\
\hline Article history & \multirow{10}{*}{$\begin{array}{l}\text { The epidemic that ravaged the world has had impact on every element of } \\
\text { human endeavors, including education. This devastation was evident in } \\
\text { the speed with which several countries' ministries of education shut down } \\
\text { school activities and halted academic sessions. In the wake of the epidemic, } \\
\text { several trends and features has emerged in the higher education sector as } \\
\text { higher education institutions tries to create methods to offset the disruptive } \\
\text { impacts of the COVID-19 epidemic on their activities and operations. The } \\
\text { trends that will shape the future of the higher education industry are not } \\
\text { new. However, the epidemic on the other hand has hastened their progress. } \\
\text { It has become evident over the last year what the post-epidemic higher } \\
\text { education institutions will look like. The rapid speed of change that has } \\
\text { already begun will continue. It is in tandem to this that this paper identifies } \\
\text { and discusses some of the emerging trends and new features of higher } \\
\text { education in the epidemic period. }\end{array}$} \\
\hline Received: 17 July 2021 & \\
\hline Revised: 25 July 2021 & \\
\hline Accepted: 15 October 2021 & \\
\hline Published Online: 30 October 2021 & \\
\hline Keywords: & \\
\hline COVID-19 & \\
\hline Higher education institution & \\
\hline Epidemic & \\
\hline Trends & \\
\hline
\end{tabular}

\section{Introduction}

COVID-19 disease, caused by a coronavirus, was declared a public health emergency of international concern by the World Health Organization (WHO) on March 11, 2020. Fever, cough, exhaustion, shortness of breath, pneumonia, and acute respiratory distress syndrome are among symptoms of COVID-19 disease, which has led to mortality in some cases (WHO, 2020). According to a UNESCO report, Coronavirus (COVID-19) began spreading fast over the world in late December 2019, killing over 3000 people ${ }^{[14]}$. As a result, numerous governments have implemented a variety of strict measures, including national lockdown and social isolation, as well as the closure of educational institutions, in order to prevent the virus from spreading further. According to Huang et al., (2020), as of March 12th, 2020, 46 countries across five continents had declared the shutdown of schools, including tertiary institutions, in order to contain the spread of COVID-19. Because there has been no specific antiviral treatment, prevention has mostly been used to control its spread ${ }^{[5,11]}$.

The epidemic that ravaged the world has had impact on every element of human endeavors, including education. This devastation was evident in the speed with which several countries' ministries of education shut down school activities and halted academic sessions. The global epidemic has had the most damaging effect on

*Corresponding Author:

Joseph Eleojo Victor,

School of Civil Engineering, Central South University, Changsha, Hunan, 410075, China; Department of Civil Engineering, Faculty of Engineering, Ahmadu Bello University Zaria, Kaduna State, 800242, Nigeria;

Email: jaser1901@csu.edu.cn 
schools that do not possess an e-learning infrastructure. This was the case in higher institutions in Africa, while in developed nations like the United States, Canada and United Kingdom, school's educational revenue and income took a diminishment. According to the report by ${ }^{[15]}$, the closure of educational institution has impacted over $91 \%$ of the world's student population.

According to ${ }^{[16]}$, nearly half of the world's students are still affected by partial or complete school cancellations a year after the COVID-19 global epidemic began, and over 100 million more children will fall below the minimum reading competency level as a result of the health catastrophe. Despite global efforts to combat the COVID-19 epidemic one year later, significant disruptions remain in the reopening of schools, education and training systems.

In the wake of the epidemic, several trends and features has emerged in the higher education sector as higher education institutions try to create methods to offset the disruptive impacts of the COVID-19 epidemic on their activities and operations. Though these trends have obvious deficiencies and weaknesses as seen in the inexperience of teachers, complex environment at home, weakness of e-learning infrastructure (Murtgatrotd, 2020). However, the epidemic situation demanded definite intentional action to mitigate its effect on the education of students. Most notable is the "Suspending Classes without Stopping Learning" a policy initiated by the Chinese government to ensure that learning was not affected by the epidemic ${ }^{[20]}$. This study or paper will examine some of the trends and features of higher education during the epidemic.

The findings of this paper are significant in all regards and of great importance to various stakeholders involved in the educational sector. This study will provide educational authorities with crucial information on emerging trends in higher education, such as ICT, so that they can include them as pedagogical improvements in education. Furthermore, the findings of this study will aid higher education institutions by providing them with useful information that will help them improve their curricula and better educate teachers to deal with the epidemic's various challenges.

\section{Methodology}

Secondary sources of data were employed to perform this research. The review centered on accessible literature on the COVID-19 epidemic and higher education journal articles published in the year 2020 during the epidemic period. The study's thematic area was developed using meta-analyses of qualitative literature, commonly known as meta-synthesis. Also examined were e-contents, legitimate websites, and other internet reports from national and international bodies relating to the COVID-19 epidemic and higher education institutions. The qualitative analysis of the data and information gathered throughout the review was driven by the study's topic area. Background information on the COVID-19 epidemic, its consequences on higher education institutions, the features and new trends adopted by higher education institutions during the epidemic period were among the topics covered.

\section{Findings and Discussion}

The COVID-19 epidemic makes practically every aspect of our existence questionable. Higher education institutions are scrutinizing their structure, approach, and sustainability in order to adapt and even overcome the challenge they face. As such, innovative institutions have had to pull through their operations in the face of costly operational constraint. To go beyond mere experimentation, higher education institutions are letting go of old practices, balancing pressing demands, and learning lessons, all while putting students first.

It has become evident over the last year what the postepidemic higher education sector will look like. Trends that will shape the future of the higher education industry are not new. However, the epidemic on the other hand has hastened their progress. The rapid speed of change that has already begun will continue. If we can see and adopt the developing trends and patterns, the COVID-19 epidemic period will be remembered as a time of reflection and fresh opportunity particularly in terms of more choice and cost of learning, which enabled us to serve more students in more meaningful ways.

\subsection{Bimodal Delivery of Academic Programs}

The devastating impact of the COVID-19 epidemic has left humanity with a reality that we have to live with for some time. Subsequently, it will not be possible for higher education institutions to return to normal operations anytime soon. As such, a combination of face-to-face and online learning is the new norm. Many higher education institutions have adopted e-learning as a way to avoid completely disrupting their academic calendar. These institutions have taken advantage of the critical role that information and communication technology (ICT) plays in everyday life to revolutionize the learning environment, using ICT tools to facilitate learning throughout the global epidemic. College and universities have adopted a number of e-learning platforms however, these platforms 
are in exhaustive. Zoom, Tencent Meeting, QQ-meeting, Microsoft Teams, Google Hangout (meet), Skype, Bamboo Learning, Google Classroom, and so on are just a few examples.

The COVID-19 epidemic caused many institutions of higher education to turn to e-learning platforms out of necessity and a sense of urgency ${ }^{[18]}$. This is only the beginning. Technology will continue to play a critical role in classrooms including how assessments are produced, textbooks are distributed, communication occurs and even internships are conducted. For example, during the pandemic in July-August 2020, Central South University's third-year civil engineering students completed their internship online. How did this happen? Experts from several fields of civil engineering, as well as professionals working outside of academia, were invited to discuss their research with the students and the project they were working on, respectively.

The erratic pace of ICT progress can be seen in advanced countries' inventive development, such as Japan's use of robotics to perform a virtual convocation ceremony for its students ${ }^{[10]}$. Business Breakthrough University (BTT) in Japan devised a brilliant method of holding a graduation ceremony without the students being physically present. Instead of them, the graduates used remote-controlled robots to accept their degrees.

The COVID-19 epidemic has shown that, while good physical infrastructure is important for a good learning environment, it may also be excessive ${ }^{[2]}$. As a result, higher education institutions are investing more in ICT infrastructure and employees to provide the necessary technological assistance. During this digital shift to global virtual learning, institutions' commitment to invest in userfriendly technology for a seamless experience can help overcome time, technological, and location constraints to learning.

\subsection{Transition to Entrepreneurial University}

The epidemic occurs at a time when government financing for higher education has been dropping, and governments have slashed funding for higher education as a result of mounting fiscal constraints ${ }^{[4]}$. A decline in revenue in the form of students' tuition fees and donor-funded research due to the COVID-19 epidemic has impacted the financial health of higher education institutions. This is a reality most higher education institutions in developing countries must accept because resources in the form of government funding are channeled to other sectors of the economy expected to play acritical role in economic recovery as Altbach \& de Wit (2020) mentioned ${ }^{[3]}$. UNESCO (2020) and the World
Bank (2020) have warned that worldwide support for higher education, research partnerships, and partnership schemes, which is typically targeted at vital areas like boosting Ph.D. programs, could plummet.

One year into the global epidemic, higher education institutions have realized that the transition into the entrepreneurial university is unavoidable. This is made possible as higher education institutions are learning through strategic community engagement, cover the financial deficit by generating additional revenue through symbiotic relationships in knowledge, technology transfer, and resource exchange activities ${ }^{[2]}$.

$\mathrm{As}^{[2]}$ point out, the shift to an entrepreneurial university is not a simple process. It is a deliberate, conscious, systematic, and rational transition to profit-making institutions through strategic community engagement. Only through recognizing, implementing, and supporting entrepreneurial behaviors, orientation, education, structures, practices, culture, and research across the entire system will this be accomplished ${ }^{[13]}$.

\subsection{Institutionalized Contingency Planning}

Even the best-rated higher education institutions can be swamped by a pandemic breakout if they lack contingency preparedness, as the COVID-19 worldwide epidemic has revealed. One year into the epidemic, higher education institutions have realized and acknowledged the need to outgrow from situational to strategic, proactive and inventive responses to catastrophes and emergencies ${ }^{[7]}$. As noted by ${ }^{[2]}$, previously, spontaneous responses motivated solely by institutional survival have almost always resulted in turmoil, jeopardizing the institution's essential ideals. As a result, higher education institutions have made disaster and emergency contingency planning mandatory in order to prevent, prepare for, reduce, respond to, and recover from future occurrences of such occurrences, reducing operational disruption and psychological repercussions on students and staff.

\subsection{Virtual Assessment of Learners}

Assessment lies at the heart of the teaching process ${ }^{[1]}$. The impact of the COVID-19 epidemic which has resulted in a shift from face-to-face to full-time online learning, has also impacted institution's ability to assess students' performance. This was exacerbated by the fact that the majority of teachers and students transitioned to e-learning with little or no experience with virtual evaluations. The goal of assessment is to test the understanding of students and determine their ability to progress to the next.

Months into the epidemic, higher education institutions 
in China, made a breakthrough viz the "TronClass" application. TronClass is a mobile application that combines a variety of teaching resources to provide the most interactive teaching experience. It supports multiple application scenarios such as learning management, flipped classrooms, smart classrooms and so forth. With the mobile APP, it fully covers the PC and mobile terminals, and realizes fragmented learning, zero storage and integration, homework, testing, discussion, and interaction, it's like bringing the classroom with you in your pocket and getting the latest course dynamics in real time ${ }^{[8]}$.

Central South University used the TronClass and teachers were able to assess students, how? On the TronClass application, students operate from a personal account while teachers operate from institutional account, the teacher asked the students to go into their TronClass account and take the test that the teacher would administer while watching everyone through their webcam during the online class on QQ meeting or Tencent conference. The teacher has control over the amount of time and questions that the students view; in the end, the assessment goal is met because students can see their score in their personal account. Students can then ask questions to find out what the correct solution is.

While many schools struggle with how to give end-ofsemester exams online, higher education institutions are advised to adopt TronClass as it would help them achieve their intended goal of evaluation and quality assurance.

\subsection{Greater Emphasis on Lowering College Cost}

The COVID-19 epidemic has thrown higher education institutions into disarray ${ }^{[9]}$, with most classes and assessments moving online for the remainder of the academic year. With so many indicators pointing to a significant drop in revenue for higher education institutions, tuition fees have been called for to be cut (or even eliminated), which has sparked heated debate among students and faculty.

However, some institutions are taking measures to reduce the impact of the global epidemic, a report on Forbes (2021) mentioned, "Student loan debt should not increase as a result of the COVID-19 epidemic unless it impacts the time-to-completion. Colleges and universities are taking great efforts to ensure this will not be the case. Many already have announced tuition freezes for next year, and some are even offering lower tuition or other incentives to continue enrollment and degree progression".

Recently, Ohio State University recently announced it intends to be the first public university to offer a "zerodebt" bachelor's degree "at scale" ${ }^{[18]}$. What does this imply for institutes of higher learning? It means that more public institutions will provide tuition-free education to students, making it easier for them to graduate debtfree. Because of the aforementioned variables, the cost of higher education will fall for many students from all socioeconomic backgrounds. This is a tremendous accomplishment.

\section{Conclusions}

What this entails for any higher education institution depends on its position in the higher education landscape. However, every institution will need to take action and, hopefully do so, having this question in mind: How do we improve student learning in ways that empowers them to be the architect of their lives? This can only be achieved if we are able to create a working environment within the institution that attracts and retains talented people to the higher education sector. Higher education institution must go beyond mere experimentation, let go of old practices, balancing pressing demands, and learning lessons, all while putting students first.

The COVID-19 epidemic offers us a unique opportunity to learn from one another in real time as no university or higher institution of learning is alone in dealing with the devastating impact of the epidemic. The epidemic has had and will continue to have a drastic impact on higher education institutions. As a result, it is important that education administrators and other stakeholders in the education sector, respond quickly to incorporate new trends and adopt emerging features of higher education in the wake of the epidemic. Cooperation can help institutions establish strategies that will aid them in effectively adopting emerging trends in higher education, by implementing to see what works and what doesn't, and adhering to what works.

While higher education institutions can aim to provide consistently high-quality teaching and communication to students, it is critical that they listen to students' wants and concerns and use the most up-to-date technology resources for engaging in genuine discussions and creating a more active and inclusive student body.

Policymakers and other education authority stakeholders are being persuaded to enlist the assistance of professional corporations to assist them in adopting these new emerging trends and faces of education in order to mitigate the global epidemic's already existing impact on higher education institutions. While remote learning has taken center stage in the wake of the COVID-19 epidemic, leaders and education administrators are being urged to collaborate with all stakeholders in the education sector to ensure active participation, for improved quality of 
e-learning so as to minimize the negative effects of the shift from face-to-face learning to e-learning.

The trends that will shape the future of the higher education industry are not new. However, the epidemic on the other hand has hastened their progress. It has become evident over the last year what the post-epidemic higher education institutions will look like. The rapid speed of change that has already begun will continue. If we can see and adopt the developing trends and patterns, the COVID-19 epidemic period will be remembered as a time of reflection and fresh opportunities.

\section{References}

[1] Abduh, Mariam. (2021). Full-time Online Assessment during COVID-19 Lockdown: EFL Teachers' Perceptions.

[2] Augustine, Kara. (2021). COVID-19 Pandemic and Possible Trends for the Future of Higher Education: A Review. 9-26. 10.22555/joeed.v8i1.183.

[3] Altbach, P. G. \& de Wit, H. (2020). Post-pandemic outlook for higher education is bleakest for the poorest. International Higher Education, 102, 3 - 5.

[4] Blankenberger, B. \& Williams, A. M. (2020). COVID and the impact on higher education: The essential role of integrity and accountability. Administrative Theory \& Praxis, 42(3), 404-423. https://doi.org/10.1 080/10841806.2020.1771907.

[5] Di Gennaro, F., Pizzol, D., Marotta, C., Antunes, M., Racalbuto, V., Veronese, N., \& Smith, L. (2020). Coronavirus diseases (COVID-19) current status and future perspectives: A narrative review. International Journal of Environmental Research and Public Health, 17(8), 2690.

[6] DePietro, A. (2020). Impact Of Coronavirus (COVID-19) On College Tuition and Finances. Retrieved from: https://www.forbes.com/sites/andrewdepietro/2020/06/02/impact-covid-19-tuition-finance/?sh=29d5fcd84b88.

[7] Hyseni Duraku, Zamira \& Hoxha, Linda. (2020). The impact of COVID-19 on higher education: A study of interaction among students' mental health, attitudes toward online learning, study skills, and changes in students' life.

[8] https://www.tronclass.com.tw/.

[9] Julia, G. (2021). Universities Changing Tuition Fees in Response to Coronavirus. Retrieved from: https://www.topuniversities.com/student-info/student-finance/universities-changing-tuition-fees-re- sponse-coronavirus\#top_menu.

[10] Kacerauskas, M. and Kusaityte, J. (2020). Japanese University Found a Genius Solution for Their Graduation Ceremony During the Coronavirus Pandemic. Retrieved from: https://www.boredpanda.com/quarantine-covid-19-graduation-bbt-university-

[11] Khadka, S., Hashmi, F. K., \& Usman, M. (2020). Preventing COVID-19 in low-and middle-income countries. Drugs \& Therapy Perspectives, 36(6), 250252.

[12] Murgatrotd, S. (2020). COVID-19 and Online Learning.

[13] Pugha, R., Lamine, W., Jack, S. \& Hamilton, E. (2018). The entrepreneurial university and the region: What role for entrepreneurship departments? European Planning Studies, 26(9), 1835-1855.

[14] UNESCO, (2020a). COVID-19 and higher education: Today and tomorrow; Impact analysis, policy responses and recommendations. http://pubdocs. worldbank.org/en/621991586463915490/WB-Tertiary-Ed-and-COVID-19-Crisis-for-public-use-April-9. pdf.

[15] UNESCO (2020b). UNESCO COVID-19 Education Response - Education Sector Issue Notes. https:// reliefweb.int/sites/reliefweb.int/les/resources/75890. pdf.

[16] UNESCO. (2021). Education: From disruption to recovery. Retrieved from: https://en.unesco.org/ covid19/educationresponse.

[17] UNESCO. (2020). COVID-19 Educational Disruption and Response. Retrieved from https://en.unesco. org/covid19/educationresponse/.

[18] Weinberg, A. (2021). Five higher education trends the pandemic is accelerating. Retrieved from: https:// earthwatch.org/stories/teaching-pandemic-how-educators-are-handling-sudden-shift-distance-learning? gclid=CjwKCAjwieuGBhAsEiwA1Ly_nXEUcZ6lqeNODI3OvWLXAsXBu0P169XVzk12gGry9dzuSZNjHwC5XBoC-HUQAvD_BwE.

[19] WHO (2020) Coronavirus disease (COVID-19) advice for the public. https://www.who.int/emergencies/ diseases/novel-coronavirus-2019/advice-for-public.

[20] Zhang, W., Wang, Y., Yang, L., \& Wang, C. (2020). Suspending ClassesWithout Stopping Learning: China"s Education Emergency Management Policy in the COVID-19 Outbreak. Journal of Risk and Financial Management, 13(55), 1-6. https://doi. org/10.3390/jrfm13030055. 